\title{
The Role of Demographics on Decision-Making Styles of Botswana's Retail Shoppers
}

\author{
Oluranti Sangodoyin (Corresponding Author) \\ Gaborone Institute of Professional Studies, P.0. Box 1299, Gaborone, Botswana \\ Tel: 002673914933, Fax: 002673162834,Email: olurantisangodoyin@yahoo.com
}

Rina Makgosa

University of Botswana, Department of Marketing

Private Bag UB00701, Gaborone, Botswana

Tel: 002673554060, Fax: 002673185102,Email: makgosa@mopipi.ub.bw

Received: March 30, 2014 Accepted: April 14, $2014 \quad$ Published: April 21, 2014

doi:10.5296/rbm.v1i2.5519 URL: http://dx.doi.org/10.5296/rbm.v1i2.5519

\begin{abstract}
The current paper presents findings on key decision-making styles adopted by retail shoppers and how such styles are influenced by gender, age, education, income and marital status in an attempt to facilitate a sound understanding of retail shopping behavior. The sampling unit consists of the general shopping public whose age ranges from 18 to 64 years residing in Gaborone and Francistown. Gaborone and Francistown are the two largest cities with a combined population of approximately $20 \%$ of the two million people in Botswana. Data was collected by way of mall intercepts from a sample of 894 retail shoppers. Findings reflected that retail shoppers in Botswana are best described by three decision-making styles - time energy conserving, perfectionism and fashion-hedonistic consciousness. Time energy conservers were found to be old and less educated males. Perfectionistic shoppers were younger, more educated and married females. Fashion-hedonistic consciousness was common among older and married female shoppers. It is crucial for retailers to have an extensive knowledge of the role of demographics on consumers' decision-making styles in order to ensure competitive advantage through the use of appropriate marketing strategies.
\end{abstract}

Keywords: Botswana, decision-making styles, demographics, fashion-hedonistic consciousness, perfectionism, time energy conserving 


\section{Introduction}

The retail sector in Botswana has experienced significant developments owing to a substantial increase in the number of retail investments established in the past 10 years (Emongor \& Kirsten, 2009). According to the Kearney Global Retail Development Index (2012), the retail market in Botswana is the most attractive in Sub-Saharan Africa and among the top 30 attractive markets for retail investment in developing countries. The popularity of regional retail chains and the mushrooming of new malls increase the number of retail products, brands and promotional activity in Botswana. These changes stimulate distinctive patterns of retail shopping behavior which compounds complexity in the retail market. Thus, it is critical to constantly track retail shopping behavior in Botswana in relation to how shoppers handle complexities in the retail market environment.

The available literature has acknowledged that shoppers go through retail market complexity by adopting different decision-making styles such as perfectionism; brand consciousness; novelty-fashion consciousness; recreational-hedonistic consciousness; price and "value for money" consciousness; impulsiveness; confusion over choice; and habitual-brand loyal orientation (Sproles \& Kendall, 1986; Mitchell \& Bates, 1998; Mokhlis \& Salleh, 2009). Consumer decision-making styles have a far-reaching impact on retail market complexity because they are directly linked to retail shopping behavior (Mitchell \& Bates, 1998) and aid the development of more effective ways of targeting and communicating with retail shoppers (Fan \& Xiao, 1998; Walsh et al., 2001; Mitchell \& Walsh, 2004).

Despite the accumulating studies on consumer decision-making styles, there is a tendency for scholarly attention on issues such as the decision-making styles of students as retail shoppers (Sproles \& Kendall, 1986; Mokhlis \& Salleh 2009), gender differences that exist in the styles (Mitchell \& Walsh, 2004; Bakewell \& Mitchell, 2003) and the applicability of decision-making styles across different cultures (Hafstrom et al., 1992; Andrews et al., 1993; Leo et al., 2005). Limited academic research has been directed to consumer decision-making styles of non-student retail shoppers (Walsh et al., 2001), decision-making styles of specific age groups (Bakewell \& Mitchell, 2003) and other determinants of such styles (Wesley et al., 2006).

Thus, in order to add further insight into the behavior of retail shoppers when faced with growing complexity in the retail market, the current study adopts a set of demographics that are fundamental in predicting the decision-making styles of the general shopping public. The objective of the current study is to investigate the role that age, gender, education, income and marital status play in the adoption of decision-making styles by retail shoppers in Botswana.

\section{Literature Review}

\subsection{Botswana's Attractiveness to Foreign Retailers}

Botswana has enjoyed a tremendous increase in the number and size of retail businesses in recent times. The wholesale and retail sector is characterized by the highest number of established businesses in Botswana and the number continues to rise over time (Census of Enterprises and Establishments Report, 2010). To date, there are 3,412 wholesale and retail businesses operating within the country. Within the Southern African Development 
Community (SADC) region, Botswana was ranked as fourth after South Africa, Zimbabwe and Namibia based on the number of supermarkets (Emongor \& Kirsten, 2009). The increase in the number of retail establishments in Botswana has been stimulated by the inflow of large retail chain stores mainly from South Africa and the relaxation of restrictions on the inflow of foreign direct investment by Government (Policy Brief, 2008). According to the National Development Plan (2003/2008), the stock of foreign direct investment from the retail sector in Botswana which is at $8 \%$ is more than that of a majority of other economic sectors such as Financial, Hospitality and Construction. The Kearney Global Retail Development Index (2012) rated the retail market in Botswana as one of the most attractive for foreign large chain investors and Botswana was perceived as the only country to be included in the list of the top most attractive markets for global retailers in Sub-Sahara Africa. This trend accentuates prospects for expansion in the retail sector in Botswana (Benza, 2012), which is symbolized by the development of multiple modern looking malls and shopping centers across the country. The significant changes occurring in the retail sector in Botswana provides consumers with tremendous choice and new shopping experiences.

Botswana is a country in the SADC region with a population of only 2 million (Botswana Housing and Population Census, 2011). The population of Botswana consists of many tribes which possess some differences and similarities in various cultural components such as art and crafts, myths and legends, ceremonies and celebrations, beliefs and values (Botswana Vision, 2016). In spite of the differences, about $80 \%$ of the population embrace 'Setswana' as the national language and English is mutually accepted as the official language (Molosi, 2013). There is also a high degree of intermarriages and non-discriminatory attitude towards land ownership across the country that has played a significant role in ensuring cultural homogeneity. People from Botswana are also perceived to be humble, principled and welcoming, which is rooted in the value of 'botho' (Botswana Vision, 2016). Despite being landlocked with a culturally diverse and relatively small market, Botswana offers numerous characteristics that are immensely attractive to large foreign retailers. Not surprisingly, in 2013 a large United States based retail giant Wal-Mart acquired the operations of Massmart Holdings Limited a South African company in Botswana (http://corporate.walmart.com). In total, Wal-Mart owns 13 retail outlets in Botswana, a figure representing the second highest number of retail stores owned by Wal-Mart in a sub-Saharan country after South Africa. Similarly, a London Listed Standard Chartered bank acquired a 12\% stake in Botswana based supermarket chain, Choppies Enterprises in a bid to expand their operations to fast moving consumer goods markets (www.sundaystandard.info).

At independence in 1966, Botswana was among the 25 poorest and least developed countries in the world (Botswana Vision, 2016), with a real per Capita Gross Domestic Product (GDP) of US\$590 which was less than the sub-Saharan average of \$609 (UNICEF, 2004). Since independence in 1966, Botswana has continued to enjoy economic progress and racial harmony. Globally, Botswana has been recognized as a politically stable, peaceful and democratic country, which has a long history of sound economic growth (Doing Business in Botswana Report, 2012). The GDP for 2012 was projected at 7\%, a figure well above the expected growth rate of 5\% for sub-Sahara Africa (Kearney Global Retail Report, 2012). The 
attractiveness of the market is supplemented by solid health and educational systems, well maintained infrastructure, good financial institutions, relatively stable currency, stable inflation and an impressive record of good governance (Doing Business in Botswana Report, 2012). As one of the fastest growing economies in sub-Sahara Africa, Botswana attained the rank of middle income economy in the early 1990s (Kearney Global Retail Report, 2012; UNICEF, 2011). The economic success and the political stability of the country have positively affected the living standards of the majority of the population in both rural and urban villages (Doing Business in Botswana Report, 2012). According to the Kearney Global Retail Report (2012), Botswana is in the opening stage together with European countries such as Russia, Hungary and Poland for example based on the Global Retail Development Index (GRDI) Window of Opportunity Analysis. This signifies that there is an increase in a number of middle class consumers who are willing to explore organized retail formats which offer them new shopping experiences.

A vast majority of the people in Botswana are youthful and highly educated. For instance, about $63 \%$ of the total population falls in the age group 10 and 29 years while an adult literacy rate of $85 \%$ was achieved in 2011 (UNICEF, 2011). Additionally, consumer spending has continued to rise in Botswana over the past years despite adverse effects of the global crisis. Consumer spending recorded between 2011 and 2012 were significantly higher than of the previous years. In particular, consumer spending increased from BWP 7448.58 million (\$931.07 million) in 2004 to BWP 39188.84 million (\$4898.50 million) in 2012 (www.tradingeconomics.com). Changes occurring in the retail market in Botswana call for attention from both practitioners and academics alike. It is critical for retailers to track changes in the nature of competition while cautiously monitoring the behavioral patterns of retail shoppers so that they can effectively connect with them. From a retail marketing strategy perspective, it is useful to employ factors such as culture, psychographics and demographics to highlight meaningful differences in retail shopping behavior across different consumer segments. Thus, the current study seeks to make a contribution to the body of knowledge on retail shopping behavior by investigating the role of demographics on decision-making styles employed by retail shoppers in Botswana.

\subsection{Consumer Decision-Making Styles}

Consumer decision-making styles are mental orientations characterizing consumers' approach to making product and store choices when faced with an increasingly complex market environment (Sproles \& Kendall, 1986). Consumer decision-making styles have attracted substantial academic interest because they offer retailers guidelines on how shoppers make their choices (Bakewell \& Mitchell, 2003), are a sound basis for segmenting retail shoppers (Hanzaee \& Aghasibeig, 2008) and facilitate decisions on effective marketing strategies to adopt when targeting retail shoppers (Mitchell and Walsh, 2004). Sound knowledge of consumer decision-making styles is also relevant to public officers and consumer interest professionals whose responsibility is to educate the general public on how to function more effectively as consumers (Walsh et al., 2001).

Three approaches are important in the study of consumer decision-making styles - the 


\section{MInstitute Macrothink $^{m}$}

psychographics/lifestyles, the consumer typology and the consumer characteristics. The use of psychographics/lifestyles approach has been credited to Lastovicka (1982) who identified over a hundred general lifestyle activities and consumer choice such as price consciousness, quality consciousness, shopping enjoyment, and innovativeness. The consumer typology approach defines general consumer "types" in relation to retail patronage such as low price seeking and store promiscuity (Moschis, 1976). The consumer characteristics approach emphasizes on the cognitive and affective orientations towards purchasing (Sproles \& Kendall, 1986). The current study adopts the consumer characteristics approach because it has been perceived to be more meaningful in explaining consumer decision-making styles due to its focus on consumers' mental and cognitive orientation (Lysonski et al., 1996).

Table 1. Description of Eight Consumer Decision-Making Styles

Perfectionism/ high-quality consciousness: This style is concerned with quality. Consumers with this decision-making style will not compromise with products classified as 'good enough'.

Brand consciousness: This style is concerned with getting expensive and well-known brands. Consumers with this style believe that the higher the price of the product the better the quality. These consumers also prefer best-selling advertised brands.

Novelty- fashion consciousness: Consumers possessing this style tend to seek out new things. This style reflects a liking of innovative products and a motivation to keep up to date with new styles and fashion trends.

Recreational-hedonistic consciousness: Consumers with this style view shopping as being enjoyable. Consumers with this style enjoy the stimulation of looking for and choosing products.

Price and "value for money" consciousness: The style is concerned with getting lower prices. The presence of this style means that the consumer is conscious of sale prices and aims to get the best value for their money.

Impulsiveness: This style describes a shopper who does not plan shopping and appears unconcerned with how much he/she spends. Consumers with this style can regret their decision later.

Confused over choice: This style reflects lack of confidence and inability to manage the number of choices available. Consumers with this style experience information overload.

Habitual, brand loyal orientation: Consumers possessing this style do shopping at the same stores and buy the same brands each time.

Source: (Sproles and Kendall, 1986).

The eight consumer characteristics that were proposed by Sproles and Kendall (1986) are listed in Table 1. Empirical studies investigating consumer decision-making styles have devoted attention to testing the applicability of the eight consumer decision-making styles proposed by Sproles and Kendall (1986) across various countries such as United States 
(Hafstrom et al., 1992; Andrews et al., 1993); Europe (Mitchell \& Bates, 1998; Walsh et al., 2001; Bakewell \& Mitchell, 2003), Asia (Fan \& Xiao, 1998; Leo et al., 2005; Mishra, 2010) and Sub-Sahara Africa (Makgosa \& Mfosi, 2006, Radder et al., 2006). The adoption of decision-making styles has been found to vary across countries. For instance, the eight styles could not be interpreted in Greece, India, New Zealand and Australia (Lysonski et al., 1996). In particular, a shopping avoidance style emerged in India instead of recreational shopping while price consciousness was not found across all the studied cultures. Hafstrom et al. (1992) also demonstrated that although brand consciousness, perfectionism, recreational, impulsiveness, confused by over choice, price consciousness and brand loyalty were common for both the United States and Korean samples, fashion consciousness was not evident among the Korean students as a new style time energy conserving was found instead. A cross-cultural study conducted by Leo, et al. (2005) on decision-making styles also emphasized that regardless of the similarities between Singaporeans and Australians on quality consciousness, recreation consciousness and brand loyalty, Singaporeans were more innovative and Australians were more brand conscious.

The eight decision-making styles (Sproles \& Kendall, 1986) also appear to be less applicable in most developing countries. For instance, only three out of eight styles namely brand consciousness, quality consciousness and price consciousness adequately described the decision-making styles of young Chinese consumers (Fan \& Xiao, 1998). Similarly, only five out of the proposed eight styles namely impulsiveness, quality consciousness, confused by over choice, brand consciousness, and brand loyalty emerged as styles describing young adult consumers in Botswana (Makgosa \& Mfosi, 2006). Several new styles have also emerged such as time energy conserving (Fan \& Xiao, 1998), information utilization (Fan \& Xiao, 1998), and shopping avoidance (Makgosa \& Mfosi, 2006). The variations in the use of decision-making styles across countries signifies the need to identify the styles that best describe the behavior of shoppers in a particular context before a decision is taken to link the styles to determinants. However, extensive research on decision-making styles is still based on samples from developed countries (Hafstrom, et al., 1992; Lysonski et al., 1996; Walsh et al., 2001; Bakewell \& Mitchell, 2003). Thus, there is limited scholarly attention paid to decision-making styles of retail shoppers in developing nations in Sub-Sahara Africa and Botswana in particular.

Prior research has primarily focused on the link between decision-making styles and gender (Bakewell \& Mitchell, 2003; Mitchell \& Walsh, 2004; Makgosa \& Mfosi, 2006; Wesley et al., 2006). The research input on the impact of other demographic variables such as age, income, education and marital status on decision-making styles is rather insignificant. However, it has been acknowledged that demographic characteristics are closely related to retail shopping behavior (Ailawadi et al., 2001; Wesley,et al., 2006; Mishra, 2010). The approach to studying the role of demographics on retail shopping behavior is attributed to the model of consumer decision-making (Blackwell et al., 2001) and the theory of antecedents and consequences of consumer decision-making styles (Wesley et al., 2006). Although the models/theories vary in the structure of presentation and the proposed determinants, they have generally outlined that the behavior of consumers is predicted by various variables such as demographics, 
psychographics, socio-cultural factors and the marketing mix. Demographic characteristics have been of interest to marketers because they are considered to be the most cost effective ways of market segmentation (Ailawadi et al., 2001; Mishra, 2010) and are useful in revealing on-going trends that may signal new business opportunities in the market (Zeithmal, 1985). Therefore, an investigation of how selected demographics affect decision-making styles used by retail shoppers in Botswana offer a sound perspective of retail shopping behavior.

Additionally, except for a few studies conducted on samples of the general shopping public (Leo et al., 2005; Walsh et al., 2001; Wesley et al., 2006), almost all the other related past studies have relied heavily on student samples. Other scholars have cautioned that the measurement scale of consumer decision-making styles needs to be validated using non-students samples (Hafstrom et al., 1992; Lysonski et al., 1996). The use of student samples has also been strongly criticized for eliminating the potential to generalize the results to the entire population (Sproles \& Kendall, 1986; Walsh et al., 2001; Wesley et al., 2006).

Therefore, in order to contribute to the body of knowledge in decision-making styles the current study examines the influence of key demographics including gender, age, education, income, and marital status on consumer decision-making styles as opposed to simply concentrating on only one explanatory variable at a time. Additionally, this investigation focuses on styles that best describe the behavior of shoppers in Botswana, a context that has a great potential for retail growth utilizing a sample of the general shopping public instead of students.

\section{Hypotheses Development}

\subsection{Gender and Decision-Making Styles}

Gender has been identified in a considerable number of previous studies as a significant factor in explaining differences in decision-making styles (Mitchell \& Walsh, 2004; Makgosa \& Mfosi, 2006; Hanzaee \& Aghasibeig, 2008; Mokhlis \& Salleh, 2009). However, no consensus exists about the relationship between gender and consumer decision-making styles. Although studies on gender differences on consumer decision-making styles have generated inconsistent findings, perfectionism, brand consciousness, confused by over choice and impulsiveness emerged as common styles for both male and female shoppers (Mitchell \& Walsh, 2004; Makgosa \& Mfosi, 2006; Hanzaee \& Aghasibeig, 2008; Mokhlis \& Salleh, 2009).

Several new styles rather than the proposed eight have also been identified in many of the studies that examined gender differences, which compounds the problem of understanding the link between gender and consumer decision-making styles. For instance, females and males did not significantly differ in the use of enjoyment fashion seeking and store loyalty (Makgosa \& Mfosi, 2006) as well as satisfying and value seeking (Mokhlis \& Salleh, 2009). Although similarities have been observed between both males and females, some differences have been reported in previous studies. For instance, satisfying, enjoyment seeking, fashion-sale seeking, time restricted and economy seeking were found to be common 
amongst males while females exhibited novelty-fashion consciousness, high quality consciousness, recreational shopping (Wesley et al., 2006) as well as time energy conserving and variety seeking (Mitchell \& Walsh, 2004). Males also exhibited brand loyalty and time energy conserving (Mokhlis \& Salleh, 2009). Females were found to be more fashion conscious, price conscious and likely to avoid shopping than males (Makgosa \& Mfosi, 2006; Mokhlis \& Salleh, 2009). Similarly, females were likely to exhibit recreational quality seeking, recreational discount seeking, lack of interest on shopping and fashion, and loyalty on trend setting (Bakewell \& Mitchell, 2003). Therefore considering the above studies, it is hypothesized that:

H1: Females are more likely to adopt (a) perfectionism, (b) price consciousness, (c) impulsiveness, (d) fashion consciousness, (e) recreational consciousness, (f) confused by over choice while males are more likely to use (g) brand consciousness and (h) brand-loyalty in Botswana.

\subsection{Age and Decision-Making Styles}

Studies of consumer decision-making styles of younger retail shoppers dominate the literature. For example, under graduate students aged between 18 and 22 years in the UK were found to be seeking recreational quality and discounts, uninterested in shopping and fashion, loyal trend setters and confused, time and money conservers (Bakewell \& Mitchell, 2003). Mishra (2010) identified perfectionism, brand consciousness, dissatisfied shopping consciousness, fashion consciousness, price-value consciousness, impulsiveness, recreational-hedonism, confused by over choice, store and brand loyalty as widely used by high school students in India. University students aged between 18 and 25 years in China adopted brand consciousness, high quality consciousness, price consciousness, time energy and information utilization (Fan \& Xiao, 1998). Perfectionism, brand consciousness, confused by over choice, impulsiveness, satisfying and value seeking emerged as unique styles for undergraduate students aged about 21 years in Malaysia (Mokhlis \& Salleh, 2009).

Generally, previous studies have demonstrated that young retail shoppers are more likely to display high quality consciousness, brand consciousness, impulsiveness, price consciousness, confused by choice, and recreational shopping. Brand loyalty and novelty consciousness were not common styles in most reviewed studies that were based on young adults. Although research into how decision-making styles vary according to age has been limited as young adults are relatively comparable on the basis of most demographics, it was noted that age could possibly explain differences in decision-making styles. In particular, Bakewell and Mitchell (2003) argued that younger retail shoppers exhibit different shopping behavior patterns and attitudes from other age groups. Ailawadi et al. (2001) noted that older people are more likely to enjoy shopping and are less likely to seek for variety and conserve time. Pandraud and Lauret (2010) also suggested that older shoppers prefer well established brands and are attached for a long time while younger shoppers have a greater propensity to adopt novel products. Similarly, compared to young shoppers, older shoppers were more inclined to shop frequently, plan more for shopping and use more information to economize (Zeithmal, 1985). It is therefore hypothesized that: 
H2: Young retail shoppers are more likely to adopt (a) perfectionism, (b) price consciousness, (c) Impulsiveness, (d) recreational shopping, (e) confused by over choice while older consumers are more likely to use (f) fashion consciousness (g) brand consciousness, and (h) brand loyalty in Botswana.

\subsection{Education and Consumer Decision-Making Styles}

Previous studies have rarely investigated whether decision-making styles vary according to education. It was found that highly educated shoppers are more likely to be quality conscious and fashion hedonistic and less likely to be pressurized by time than those who are less educated (Ailawadi et al., 2001). Smadi and Al-Jawazneh, (2011) also revealed that highly educated young shoppers are high quality conscious, price conscious, impulsive, confused over choice, brand-loyal than less educated shoppers. Highly educated shoppers appear to shop frequently on the internet for books and personal computers than low educated shoppers (Girard et al., 2003). Studies based on samples of young adults in higher education have indicated that they commonly use high quality consciousness, brand consciousness, recreational shopping, confused by over choice, and impulsiveness (Hafstrom et al., 1992; Canabal, 2002; Makgosa \& Mfosi, 2006). Thus from these findings, it is hypothesized that:

H3: Highly educated retail shoppers are more likely to adopt (a) perfectionism, (b) priceconsciousness, (c) impulsiveness (d) recreational consciousness, (e) confused by over-choice, (f) fashion consciousness, (g) brand consciousness and (h) brand-loyalty in Botswana.

\subsection{Income and Consumer Decision-Making Styles}

Limited available research has alluded to the fact that low income shoppers depict behavior that is different from that of high income shoppers. For instance, Ailawadi et al. (2001) suggested that compared to those who have higher income, lower income shoppers are more likely to be financially constrained and price conscious. Low income consumers were also more likely to purchase food low in quality such as food with less fiber, food high in fat content, sugar and salt (Turell et al., 2002). However, impulsive shopping behavior has been found to be common among high income earners as they are less financially constrained and more likely to act on their impulses (Ghani \& Jan, 2011). Retail shoppers with more income were also more likely to seek leisure, spend time shopping and plan their shopping significantly (Zeithmal, 1985). Shoppers with more income were more inclined to buy online for products such as cell phones and televisions (Girard et al., 2003). Drawing from these studies it can be concluded that high income shoppers are likely to be impulsive, fashion-hedonistic, recreational conscious, perfectionistic and less likely to be price conscious and confused by over choice. It is therefore hypothesized that:

H4: High income retail shoppers are more likely to adopt (a) perfectionism, (b)recreational consciousness, (c) fashion consciousness, (d) brand consciousness, (e) impulsiveness, while low income shoppers are more likely to use (f) brand-loyalty, g) price consciousness and (h) confused by over-choice in Botswana.

\subsection{Marital Status and Consumer Decision-Making Styles}


Although there is no study that has investigated the relationship between decision-making styles and marital status, segments based on this variable have attracted numerous marketing efforts. In a study conducted by Zeithmal (1985) it was reported that married individuals have more time to plan, possess more positive attitudes towards shopping and use more information to economize than single people. It was further suggested that single individuals experienced more role overload leading to less time and energy devoted to shopping, considering that they perform tasks and activities that are usually undertaken by a husband and a wife. A general conclusion is that married retail shoppers are more likely to purchase high quality or branded products, seek for leisure and variety and less confused by choice whereas single people are expected to be impulsive and price conscious than married people.

\begin{abstract}
H5: Married retail shoppers are more likely to adopt: (a) perfectionism, (b) brand consciousness, (c) brand loyalty, (d) novelty-fashion consciousness, (e) recreation/hedonism consciousness while non-married shoppers are likely to use (f) price consciousness, ( $g$ ) impulsiveness and (h) confused by over choice in Botswana.
\end{abstract}

\title{
4. Research Method
}

The research design utilized in the current study was a survey employing a structured questionnaire. This design was selected based on the study objectives and it was also deemed important to conform to the study by Sproles and Kendall (1986) and previous related studies (Lysonski et al., 1996; Mitchell \& Bates, 1998). The questionnaire was pretested using a sample of 60 members of the general shopping public residing in Gaborone in order to check for clarity in the understanding of the various items. Botswana shoppers responded positively to the survey and demonstrated a good understanding of the questionnaire items during the pretesting exercise. The final questionnaire included 38 measures of consumer decision-making styles adapted from Sproles and Kendall's (1986) which were randomly arranged to avoid biasness. The questionnaire also included questions on age, gender, education, income and marital status.

The sampling unit for the study consists of the general shopping public whose age ranges from 18 to 64 years residing in Gaborone and Francistown. As noted by Walsh et al. (2001), the rate of retail and consumption activities is commonly high in cities. In fact, the two cities i.e., Gaborone and Francistown were selected because of the high concentration of retail stores and the population. In particular, although Botswana consists of sixteen administrative districts, Gaborone and Francistown constitute approximately 32\% of the established retail businesses and $20 \%$ of the population in Botswana (Census of Enterprises and Establishments Report, 2010; Population and Housing Census, 2011). The general shopping public were selected as the ideal unit of analysis because previous researchers have criticized samples that are based on students as not representative of the general population and for failing to generate results that can be generalizable (Walsh et al., 2001; Wesley et al., 2006). Numerous studies on decision-making styles also demanded for an administration of the Consumer Style Inventory to the general shopping public (Sproles \& Kendall, 1986; Hafstrom et al., 1992; Lysonski et al., 1996). A rule of thumb that the minimum sample size should be ten times the number of items measured and statistical estimator for sample size determination (Hair et al., 


\section{Macrothink Allinstitute}

2010; Walsh et al., 2001) were used.

The sample was drawn using convenience sampling by intercepting the general public from Monday to Saturday in selected shopping centers for a period of six weeks. Mall intercepts were used despite the known limitations because it was extremely difficult to obtain sampling frames of the general public in Botswana that would have facilitated the use of probability sampling. As noted by Walsh et al. (2001), the key advantage for using mall intercepts is that data collected in shopping malls is likely to be based on relevant and recent opinions relating to consumer decision-making styles. Out of 1000 questionnaires distributed to the general shopping public intercepted in shopping malls, a total of 984 questionnaires were obtained back. Overall, 894 questionnaires were deemed valid for data analysis and a response rate of $89 \%$ was achieved which is comparable with the rate achieved by Walsh et al. (2001).

\section{Demographic Profile of the Sample}

Table 2. Demographic Profile of the Sample $(n=894)$

\begin{tabular}{|c|c|c|}
\hline & \multicolumn{2}{|c|}{ Sample } \\
\hline Demographic Characteristics & $\mathrm{N}$ & $\%$ \\
\hline \multicolumn{3}{|l|}{ Age (Years) } \\
\hline Young (18-34) & 553 & 62 \\
\hline Old (35 or more) & 341 & 38 \\
\hline \multicolumn{3}{|l|}{ Gender } \\
\hline Females & 504 & 56 \\
\hline Males & 390 & 44 \\
\hline \multicolumn{3}{|l|}{ Marital Status } \\
\hline Not married $^{\#}$ & 649 & 73 \\
\hline Married & 245 & 27 \\
\hline \multicolumn{3}{|l|}{ Education } \\
\hline More educated $^{\# \#}$ & 726 & 81 \\
\hline Less educated $^{\# \# \#}$ & 168 & 19 \\
\hline \multicolumn{3}{|c|}{ Personal Monthly Income (approx. USD1 = P8.00) } \\
\hline Low income (Less than P5000) & 437 & 49 \\
\hline High income (More than P5000) & 457 & 51 \\
\hline
\end{tabular}

Notes: ${ }^{\#}$ include Divorced, Widowed, Living together and Separated, Never married);

\#\# include tertiary Certificate, Tertiary Diploma, Tertiary Bachelor's Degree and Tertiary Higher Degree; ${ }^{\# \#}$ include No Formal Education, Pre Primary School, Primary Education, Junior Cert. Education, Senior Cert. Education.

The demographic profile of the sample was computed using Frequency tabulations. The 


\section{Macrothink

results in Table 2 above show that, a majority of the respondents (62\%) are young retail shoppers who fall in the age group 18 to 34 years. The sample also has a relatively high proportion of females at $56 \%$. A significant percentage of the sample is not married including singles, separated and widowed (73\%), highly educated having obtained more than senior secondary school certificate $(81 \%)$, and high income earners with annual salaries greater than P5000 (51\%). These demographic statistics correspond to the general population statistics of Botswana. According to the Housing and Population Census (2011), Botswana is a youthful nation $(63 \%)$ and with a relatively high proportion of females $(52 \%)$. The country is also characterized by high literacy rate $(85 \%)$ and as having middle income status.

\section{Hypotheses Testing}

Data analysis for this study proceeded in three stages. The first stage sought to identify salient items that measure consumer decision-making styles. To identify the key decision-making styles of the general shopping public in Botswana, an Exploratory factor analysis with Varimax rotation was applied on the entire sample $(n=894)$. To obtain the meaningful factors, specific items were considered for elimination using the following criteria: (i) Eigen values greater than 1 , (ii) factor loadings of .40 or above on a factor, (iii) items loading on just one factor, (iv) Kaiser criterion, and Bartlett test of Sphericity. The criteria are the same as the one that were used by Sproles and Kendall's (1986). According to Hair et al. (2010), factor loadings greater than .30 are considered to be meaningful indicators of the concept in question. The results of the exploratory factor analysis are presented in Table 3.

The final factor solution generated 7 factors based on the 33 retained measures of consumer decision-making styles. These factors have some similarities to those obtained in previous studies (Bakewell \& Mitchell, 2003, Hanzaee \& Aghasibeig, 2008, Mokhlis \& Salleh, 2009). The retained factors explained $48.94 \%$ of the total variance which is slightly higher than $46 \%$ obtained in the original study by Sproles and Kendall (1986); 47\% by Hafstrom et al. (1992); $35 \%$ by Fan and Xiao (1998); 44\% by Canabal (2002), and Mokhlis (2009). Kaiser MeyerOlkin (KMO) measure of sampling adequacy was also assessed and result is .88, which signifies that the exploratory factor analysis is appropriate. 


\section{Macrothink}

Table 3. Consumer Decision-Making Styles of Retail Shoppers in Botswana

\begin{tabular}{|c|c|c|c|}
\hline Consumer Decision-Making Styles & $\begin{array}{l}\text { Factor } \\
\text { Loadings }\end{array}$ & $\begin{array}{l}\% \text { of Variance } \\
\text { Explained }\end{array}$ & $\begin{array}{l}\text { Eigen } \\
\text { Values }\end{array}$ \\
\hline Factor 1: Time Energy Conserving & & 17.23 & 5.68 \\
\hline $\begin{array}{l}\text { I shop quickly, buying the first retail products I find that } \\
\text { seems good enough. }\end{array}$ & .75 & & \\
\hline 2. I make my retail products shopping trips fast. & .71 & & \\
\hline $\begin{array}{l}\text { 3. All the information I get on different retail products } \\
\text { confuse me. }\end{array}$ & .63 & & \\
\hline $\begin{array}{l}\text { 4. I really don't give my retail products purchases much } \\
\text { thought. }\end{array}$ & .60 & & \\
\hline $\begin{array}{l}\text { 5. A retail product doesn't have to be perfect, or the best } \\
\text { to satisfy me. }\end{array}$ & .59 & & \\
\hline 6. I enjoy shopping for retail products just for the fun of it. & .59 & & \\
\hline $\begin{array}{l}\text { 7. Often I make careless retail products purchases; I } \\
\text { later wished I had not bought them. }\end{array}$ & .56 & & \\
\hline $\begin{array}{l}\text { 8. I go to the same store each time I shop for retail } \\
\text { products. }\end{array}$ & .56 & & \\
\hline $\begin{array}{l}\text { 9. The most advertised brands of retail products are } \\
\text { usually very good choices. }\end{array}$ & .54 & & \\
\hline 10. Shopping for retail products wastes my time & .52 & & \\
\hline Factor 2: Perfectionistic/High Quality Consciousness & & 12.29 & 4.06 \\
\hline $\begin{array}{l}\text { 11. Getting very good quality retail products is very } \\
\text { important to me. }\end{array}$ & .72 & & \\
\hline $\begin{array}{l}\text { 12. I look carefully to find retail products that offer me } \\
\text { the best value for money. }\end{array}$ & .66 & & \\
\hline $\begin{array}{l}\text { 13. When it comes to purchasing retail products, I try to } \\
\text { get the very best choice. }\end{array}$ & .59 & & \\
\hline $\begin{array}{l}\text { 14. The well-known brands of retail products are the } \\
\text { best for me. }\end{array}$ & .55 & & \\
\hline $\begin{array}{l}\text { 15. I carefully watch how much I spend on retail } \\
\text { products. }\end{array}$ & .50 & & \\
\hline $\begin{array}{l}\text { 16. I prefer buying the best-selling brands of retail } \\
\text { products. }\end{array}$ & .47 & & \\
\hline $\begin{array}{l}17 . \text { I make special effort to choose the very best quality } \\
\text { retail products. }\end{array}$ & .46 & & \\
\hline $\begin{array}{l}\text { 18. In general, I usually try to buy the best overall quality } \\
\text { of retail products. }\end{array}$ & .41 & & \\
\hline $\begin{array}{l}\text { 19. Fashionable and attractive styling is very important } \\
\text { to me. }\end{array}$ & .69 & & \\
\hline
\end{tabular}


Table 3 continued.

\begin{tabular}{|c|c|c|c|}
\hline Consumer Decision-Making Styles & $\begin{array}{l}\text { Factor } \\
\text { Loadings }\end{array}$ & $\begin{array}{l}\% \text { of Variance } \\
\text { Explained }\end{array}$ & $\begin{array}{l}\text { Eigen } \\
\text { Values }\end{array}$ \\
\hline Factor 3: Fashion/Hedonistic Consciousness & & 5.47 & 1.80 \\
\hline $\begin{array}{l}\text { 20. Shopping for retail products is one of the most } \\
\text { enjoyable activities of my life. }\end{array}$ & .63 & & \\
\hline $\begin{array}{l}\text { 21. I keep my wardrobe up-to-date with the changing } \\
\text { fashions. }\end{array}$ & .61 & & \\
\hline 22. I usually have several outfits of the very newest style. & .60 & & \\
\hline $\begin{array}{l}\text { 23. The more expensive brands of retail products are } \\
\text { usually my choice. }\end{array}$ & .59 & & \\
\hline $\begin{array}{l}\text { 24. Shopping for retail products is a pleasant activity to } \\
\text { me. }\end{array}$ & .58 & & \\
\hline Factor 4: Novelty Consciousness & & 3.78 & 1.25 \\
\hline 25 . I regularly change the brands of retail products I buy. & .64 & & \\
\hline $\begin{array}{l}\text { 26. I need to plan my shopping for retail products more } \\
\text { carefully than I do }\end{array}$ & .55 & & \\
\hline Factor 5: Confused by Over-choice & & 3.62 & 1.20 \\
\hline $\begin{array}{l}\text { 27. There are so many brands of retail products to } \\
\text { choose from that I often feel confused. }\end{array}$ & .70 & & \\
\hline $\begin{array}{l}\text { 28. Sometimes it is hard for me to choose which retail } \\
\text { store to shop from. }\end{array}$ & .48 & & \\
\hline $\begin{array}{l}\text { 29. The more I learn about retail products, the harder it } \\
\text { seems to choose the best. }\end{array}$ & .45 & & \\
\hline Factor 6: Habitual Buying & & 3.49 & 1.15 \\
\hline 30. Once I find a retail product I like, I stick with it. & .73 & & \\
\hline
\end{tabular}




\begin{tabular}{|l|l|l|l|}
\hline $\begin{array}{l}\text { 31. I take the time to shop carefully for best buys for } \\
\text { retail products. }\end{array}$ & .61 & & \\
\hline Factor 7: Price Equals Quality & 3.06 & 1.01 \\
\hline $\begin{array}{l}\text { 32. The higher the quality of retail products, the better } \\
\text { the price }\end{array}$ & .62 & & \\
\hline \begin{tabular}{l} 
33. I buy retail products at sale prices. \\
\hline
\end{tabular}
\end{tabular}

The seven factors that emerged from the exploratory factor analysis were labeled as follows:

Factor 1: Time Energy Conserving. Ten items loaded in this factor. This factor achieved the highest percentage of total variance explained. Items loading on this factor show that Botswana retail shoppers shop quickly to avoid wasting time and confusion resulting from product variety. Botswana retail shoppers also prefer to make retail products shopping trips very fast and to shop without prior planning.

Factor 2: Perfectionist/High-Quality Conscious. Eight items loaded in this factor. Items loading on this factor reflect that retail shoppers in Botswana search for the very best quality in retail products. Botswana retail shoppers also prefer very high quality in retail products and will seek for the best products and brands to ensure satisfaction.

Factor 3: Fashion-Hedonistic Consciousness. Six items were loaded in this factor. Characteristics identified in this factor shows that retail shoppers in Botswana tend to prefer fashionable, latest and conspicuous styles, while also shopping for their personal enjoyment.

Factor 4: Novelty Consciousness. Only two items loaded in this factor. This factor measures shoppers' orientation towards changing brands regularly. However, this orientation makes it difficult for retail shoppers in Botswana to choose the best retail products.

Factor 5: Confused by Over-choice. Three items loaded in this factor. The factor shows that retail shoppers in Botswana are confused by the numerous retail brands and stores to choose from and the availability of multiple sources of information about retail products.

Factor 6: Habitual-Buying. Two items loaded in this factor. It reflects that in Botswana retail shoppers tend to repeat the purchase of the same brand and also thoroughly plan their shopping.

Factor 7: Price Equals Quality. This factor denotes that retail shoppers in Botswana are concerned about getting the best value for their money. Two items loaded in this factor.

In second stage, the internal consistency of each consumer decision-making style was assessed using reliability analysis with Cronbach Alpha. The reliability alpha scores of the retained consumer decision-making styles are as follows: Time energy conserving $(\alpha=.84)$; Perfectionist/high-quality consciousness ( $\alpha=.73)$; Fashion-hedonistic consciousness ( $\alpha$ $=.74)$; Novelty consciousness $(\alpha=.27)$; Confused by over-choice $(\alpha=.48)$; Habitual-buying 


\section{Al Macrothink $\Lambda$ Institute"}

$(\alpha=.34)$ and Price equals quality $(\alpha=.17)$. Time energy conserving; Perfectionist/high-quality consciousness; and Fashion-hedonistic consciousness achieved a reasonable degree of reliability of greater than .60 (Nunnally and Bernstein, 1994). Novelty consciousness, Confused by over-choice, Price equals quality and Habitual buying achieved very low reliability scores. This means that there is a need to refine their measurement as it seems the items are not good discriminatory measures in Botswana. The results also reflect that the eight decision-making styles are not consistent in other countries casting doubt on their generalizability in other contexts. The findings are similar to a study carried out by Bakewell and Mitchell (2003), which reported the reliability of only three factors namely Brand Consciousness (.76), Novelty-Fashion Consciousness (.73), Confused by Over-choice (.64) and one new factor Time Energy Conserving (.61). In another related study by Fan and Xiao (1998) only three factors namely Brand Consciousness (.61), Quality Consciousness (.54), Price Consciousness (.59), and two new factors Time Consciousness (.63), Information Utilization $(.55)$ were reliable.

Table 4. Demographics and Consumer Decision-Making Styles

\begin{tabular}{|c|c|c|c|c|}
\hline & & Males $(n=390)$ & Females $(n=504)$ & $t$ \\
\hline & $\overline{\text { GENDER }}$ & & & \\
\hline$H 1 a$ & $\begin{array}{l}\text { Perfectionism/High } \\
\text { Quality Consciousness }\end{array}$ & $4.57(.65)$ & $4.79(.65)$ & $-4.95 * * *$ \\
\hline$H 1 b$ & $\begin{array}{l}\text { Fashion-hedonistic } \\
\text { Consciousness }\end{array}$ & $3.82(.89)$ & $3.96(.92)$ & $-2.15 * *$ \\
\hline \multirow[t]{2}{*}{$H 1 c$} & Time Energy Conserving & $3.67(.93)$ & $3.44(.98)$ & $3.68 * * *$ \\
\hline & AGE & Young $(n=553)$ & Old $(n=341)$ & $t$ \\
\hline$H 2 a$ & $\begin{array}{l}\text { Perfectionism/High } \\
\text { Quality Consciousness }\end{array}$ & $4.76(.67)$ & $4.59(.64)$ & $4.10 * * *$ \\
\hline$H 2 b$ & $\begin{array}{l}\text { Fashion-Hedonistic } \\
\text { Consciousness }\end{array}$ & $3.88(.95)$ & $3.94(.84)$ & -1.02 \\
\hline \multirow[t]{2}{*}{$H 2 c$} & Time Energy Conserving & $3.39(.98)$ & $3.78(.86)$ & $-6.04 * * *$ \\
\hline & EDUCATION & $\begin{array}{l}\text { Less Educated } \\
(\mathrm{n}=168)\end{array}$ & $\begin{array}{l}\text { More Educated } \\
(\mathrm{n}=726)\end{array}$ & $t$ \\
\hline$H 3 a$ & $\begin{array}{l}\text { Perfectionism/High } \\
\text { Quality Consciousness }\end{array}$ & $4.54(.58)$ & $4.73(.67)$ & $-3.32 * * *$ \\
\hline$H 3 b$ & $\begin{array}{l}\text { Fashion-Hedonistic } \\
\text { Consciousness }\end{array}$ & $3.92(.85)$ & $3.89(.92)$ & 0.23 \\
\hline \multirow[t]{2}{*}{$H 3 c$} & Time Energy Conserving & $3.81(.88)$ & $3.48(.97)$ & $4.13 * * *$ \\
\hline & INCOME & Low $(n=437)$ & High $(n=457)$ & $t$ \\
\hline$H 4 a$ & $\begin{array}{l}\text { Perfectionism/High } \\
\text { Quality Consciousness }\end{array}$ & $4.72(.65)$ & $4.66(.81)$ & 1.39 \\
\hline$H 4 b$ & $\begin{array}{l}\text { Fashion-Hedonistic } \\
\text { Consciousness }\end{array}$ & $3.86(.90)$ & $3.94(.92)$ & -1.32 \\
\hline
\end{tabular}




\begin{tabular}{|l|l|l|l|l|}
\hline$H 4 c$ & Time Energy Conserving & $3.49(.94)$ & $3.59(.95)$ & -1.47 \\
\hline$H 5 a$ & $\begin{array}{l}\text { Perfectionism/High } \\
\text { Quality Consciousness } \\
(\mathrm{n}=245)\end{array}$ & $4.60(.68)$ & $4.73(.64)$ & $\mathrm{t}$ \\
\hline$H 5 b$ & $\begin{array}{l}\text { Fashion-Hedonistic } \\
\text { Consciousness }\end{array}$ & $3.82(.89)$ & $3.94(.91)$ & $-1.99^{*}$ \\
\hline$H 5 c$ & Time Energy Conserving & $3.55(.97)$ & $3.53(.96)$ & .13 \\
\hline
\end{tabular}

Notes: Significance level: ${ }^{* * *} \mathrm{p}=.001 ; * * \mathrm{p}=.01 ; * \mathrm{p}=.05$.

In the third stage, t-tests were used to examine whether decision-making styles of retail shoppers in Botswana vary by gender, education, marital status, income and age. Table 4 above illustrates the statistical analysis relating to the impact of demographics on decision-making styles. For the purpose of this analysis, the three reliable strategies were used and the hypotheses have been restated as follows:

H1: Female retail shoppers are more likely to adopt (a) perfectionism and (b) fashion hedonistic consciousness while male retail shoppers are (c) time energy conservers.

The results display that there are significant gender differences in all the three decision-making styles in Botswana. As hypothesized, males exhibit a higher level of the time energy conserving style than females. The difference of means of males and females on the perfectionism and fashion consciousness styles are also statistically significant and indicate that women are more likely to be perfectionistic and fashion conscious. Thus, H1 is supported.

H2: Young retail shoppers are more likely to adopt (a) Perfectionistic/high-quality consciousness and old shoppers are more likely to be (b) Fashion hedonistic consciousness and (c) time energy conserving.

The results in Table 4 show that as hypothesized young retail shoppers have a perfectionistic orientation more than older shoppers. Older retail shoppers tend to be more time energy conserving and fashion hedonistic consciousness than younger shoppers. However, the relationship between fashion-hedonistic consciousness and age is insignificant. Thus, H2a and $2 \mathrm{c}$ were supported.

H3: Highly educated retail shoppers are more likely to adopt (a)

Perfectionistic/high-quality consciousness, (b) fashion-hedonistic consciousness and

(c) time energy conserving than those who are less educated in Botswana.

There are significant differences on time energy conserving and perfectionism based on education level. The results show that less educated people are time energy conserving while more educated people are perfectionistic. Thus, H3a and $3 \mathrm{c}$ are supported. The results obtained from $\mathrm{H} 3 \mathrm{~b}$ are not supported. The difference between the means of less educated people and more educated people on fashion-hedonistic consciousness is statistically insignificant. 
H4: High income retail shoppers are more likely to adopt (a) Perfectionism/high-quality consciousness, (b) Novelty-fashion consciousness and (c) time energy conserving than less income retail shoppers.

Contrary to the hypothesis, the relationships of time energy conserving, fashion consciousness and perfectionism and income were found to be statistically insignificant. Thus, H4 was not supported.

\section{H5: Married shoppers are more likely to adopt (a) Perfectionism (b) Novelty-fashion consciousness and while Non-married shoppers are likely to be (c) time energy conserving in Botswana.}

As hypothesized, the results show that married retail shoppers are more likely to be perfectionistic and fashion conscious than their non-married counterparts. However, the difference on time energy conserving between married and non-married people is insignificant. Thus $\mathrm{H} 5 \mathrm{a}$ and $\mathrm{H} 5 \mathrm{~b}$ are supported while $\mathrm{H} 5 \mathrm{c}$ is not.

\section{Discussion and Conclusions}

The current study identified seven consumer decision-making styles that best describe retail shopping behavior in Botswana namely Perfectionistic/high-quality consciousness, Fashion-hedonistic consciousness, Novelty consciousness, Confused by over-choice, Habitual buying, Price equals quality and an additional decision-making style named Time energy conserving. However, only three styles achieved a reasonable level of reliability: Time energy conserving, Perfectionistic/high quality consciousness and Fashion/hedonistic consciousness. The time energy conserving style indicates that Botswana shoppers do not give much thought to their purchases and believe that shopping in retail stores is a waste of their time. Perfectionism implies that Botswana shoppers are highly concerned with getting good quality and best retail products. Fashion conscious shoppers tend to enjoy shopping and usually have one or more outfits of the newest style to keep their wardrobes up-to date. The poor reliability among the four other styles that emerged in Botswana is not only unique to this study. Bakewell and Mitchell (2003) reported good reliability scores on only four factors namely brand consciousness, novelty-fashion consciousness, confused by over-choice and time energy conserving. In another related study, Fan and Xiao (1998), only three factors namely brand consciousness, novelty/fashion consciousness, price/value consciousness achieved good reliability coefficients. This signifies the need to test for the applicability of the consumer inventory scale in other contexts.

This study also investigated whether gender, age, education, income and marital status are instrumental in explaining differences in decision-making-styles of retail shoppers in Botswana. Differences in time energy conserving style are best defined by gender, age and education. This style is portrayed by old and less educated male shoppers. Perfectionism-high quality consciousness style is best predicted by all demographics i.e., gender, age, education and marital status with the exception of income. This style is common among young, more educated and married female shoppers in Botswana. Fashion-hedonistic consciousness style was significantly linked to gender, age, and marital status. In fact, older and married female 
shoppers were more likely to be fashion-hedonistic conscious. These results demonstrate that gender and age are key in explaining consumer decision-making styles (Mitchell \& Walsh, 2004; Hanzaee \& Aghasibeig, 2008; Mokhlis \& Salleh, 2009). The mixed findings on the predictive ability of education, income and marital status suggest that there is a need to further probe the critical role of these variables as determinants of consumer decision-making styles.

Findings can be used by retailers in targeting different segments of shoppers based on demographics and consumer decision-making styles in order to achieve competitive advantage in the era of retail market complexity. For instance, considering that time conserving shoppers in Botswana who are old and less educated males appear to shop fast with minimal planning, retailers could emphasis convenience shopping by ensuring that their retail stores are easily accessible, express lines are fully functional, the store environment is comfortable and conducive, all points of sale are fully operational and the customer service is good when targeting this segment. Since high quality conscious shoppers in Botswana especially young, more educated and married females are keen on getting the best retail products, it is important for retailers to emphasize consistent quality across all well-known brands. This will require a careful selection of suppliers that will adhere to strict quality standards and requirements. Fashion-hedonistic shoppers are old and married females and also want to be up to date with changing and latest fashions and more likely to buy expensive brands. Retailers can target them by ensuring a satisfactory level of product assortment or keeping various product lines or extensions that feature the latest fashion trends in the form of styles, designs, models and colors. The study is also useful for the Consumer affairs department, by offering financial counseling to help shoppers better understand how and why they make certain consumer decisions and assist shoppers in making appropriate decisions in the marketplace.

This study extends the body of knowledge on decision-making styles by studying an under-studied context, focusing on demographic differences in decision-making styles of the general shopping public. However, the current Consumer Style Inventory does not adequately measure decision-making characteristics meaningfully in Botswana as four styles obtained low reliability coefficients. In the future, studies on the generalizability of the decision-making styles could focus on whether the factor structure of decision-making styles of retail shoppers differs between age groups. This is a necessary research avenue taking into account that previous studies on decision-making styles are predominately based on data from undergraduate students. As young shoppers are perceived to be homogeneous on a number of demographics, this might cast doubt in the applicability of the style to older shoppers. Additional determinants such as cultural values, frequency of purchase, frequency of mall visits and reference group influence could also be used to understand adoption of consumer decision-making styles in Botswana in each segment based on age. As research on decision-making styles continue to dominate the literature, it is necessary to evaluate the effects of using these styles on quality of life, consumer well-being, customer satisfaction and consumer happiness. 


\section{Macrothink}

\section{References}

Ailawadi, K. L., Neslin, S. A., \& Gedenk, K. (2001). Pursuing the value conscious consumer: store brands versus national brand promotions. Journal of Marketing, 65(1), 71-89. http://dx.doi.org/10.1509/jmkg.65.1.71.18132.0

Andrews, J. C., Durvasula, S., \& Lysonski, S. (1993). Cross-cultural generalization of a scale for profiling consumers' decision-making styles. Journal of Consumer Affairs, 27(1), 55-65. http://dx.doi.org/10.1111/j.1745-6606.1993.tb00737.x

Bakewell, C \& Mitchell, V. (2003). Generation Y female consumer decision-making styles. International Journal of Retail and Distribution Management, 31(2), 95-106. http://dx.doi.org/10.1108/09590550310461994

Benza, B. (2012). Botswana is best new market for global retailers. [Mmegi Online]. Retrieved January 5, 2013, from www.mmegi.bw

Blackwell, R. D., Miniard, P. W., \& Engel, J. F. (2001). Consumer behavior (9th ed.). New York: South Western Thomson Learning.

Botswana Consumer Spending Data. [Online]. Retrieved January 5, 2013, from www.tradingeconomics.com

Botswana Housing and Population Census. (2011). [Online] ]. Retrieved January 10, 2013, from http://en.wikipedia.org/wiki/2011

Canabal, M. E. (2002). Decision-making styles of young South Indian consumers: An $\begin{array}{lllll}\text { Exploratory Study. College Student Journal, } & 36(1),\end{array}$ http://dx.doi.org/10.5296/jmr.v4i2.1222

Central Statistics Office. (2010). Census of Enterprises and Establishments Report, Republic of Botswana, Government Printer, Gaborone.

Central Statistics Office. (2011). Population and Housing Census in Botswana. Republic of Botswana, Government Printer, Gaborone.

Darden, R. W., \& Aston, D. (1975). Psychographic profiles at patronage preference group. Journal of Retailing, 50(4), 99-112.

Doing Business in Botswana: A Country Commercial Guide for United States Investors 2012. ]. Retrieved from www.photos.state.gov/libraries/Botswana

Emongor, R. A., \& Kirsten, J. F. (2009). The impact of South African supermarkets on agricultural development in the Southern African Development Community: A case study in Zambia, Namibia and Botswana. Agrekon, 48(1), 60-84. http://dx.doi.org/10.1080/03031853.2009.9523817

Fan, J. X., \& Xiao, J. J. (1998). Consumer decision-making styles of young-adult Chinese. The Journal of Consumer Affairs, $275-293$. http:dx.doi.org/10.1111/j.1745-6606.1998.tb00410.x 
for Botswana. Botswana Government printing and publishing services.

Ghani, U., \& Jan, F. A. (2011). An Exploratory Study of impulse buying of Urban Consumers in Peshawar. International Conference on business and Economics Research. Retrieved January 30, 2013, from www.pedr.com

Girard, T., Korgaonkar, P., \& Silverblatt, R. (2003). Relationship of types of product, shopping orientations and demographics with preference for shopping on the internet. Journal of Business and Psychology, 18(1). 101-120.

Hafstrom, J. L., Chae, J. S., \& Chung, Y. S. (1992). Consumer decision-making style: Comparison between United States and Korean Young Consumers. The Journal of Consumer Affairs, 26(1), 146-158. http://dx.doi.org/10.1111/j.1745-6606.1992.tb00020.x

Hair, J. F., Wolfinbarger, M., Ortinau, D., \& Bush, R. (2010). Essentials of marketing research. $\left(2^{\text {nd }}\right.$ ed.). New York: McGraw-Hill.

Hanzaee, K., \& Aghasibeig, S. (2008). Generation Y female and male decision- making styles in Iran: are they different. The International Review of Retail, Distribution and Consumer Research, 18(5), 521-531. http://dx.doi.org/10.1080/09593960802573443

Kearney, A. T. (2012). Global retail expansion: Keeps moving on. Retrieved January 5, 2013, from http://www.atkearney.com

Lastovicka, J. L. (1982). On the validation of lifestyle traits: A review and illustration. Journal of Marketing Research, 19, 126-138.

Leo, C., Bennett, R., \& Hartel, C. E. J. (2005). Cross-cultural differences in consumer decision-making styles. Cross Cultural Management, 12(3), 32-62. http://dx.doi.org/10.1108/1352760051079860

Lysonski, S., Durvasula, S., \& Zotos, Y. (1996). Consumer decision-making styles: a multi country investigation. European Journal of Marketing, 30(12), 10-21. http://dx.doi.org/10.1108/03090569610153273

Makgosa, R., \& Mfosi, T. (2006). Gender and decision-making styles of young adult consumers in Botswana: Implications for marketing practitioners. Journal of Business Management and Training, 3(2), 25-46.

Mishra, A. A. (2010). Consumer decision-making styles and young-adult consumer: An Indian exploration. Isletme Arastirmalari Dergisi, 2(3), 45-62.

Mitchell, V. W., \& Bates, L. (1998). UK Consumer decision- making styles. Journal of Marketing Management, 14(3), 199-225. http://dx.doi.org/10.1362/026725798784959345

Mitchell, V. W., \& Walsh, G. (2004). Gender differences in Germany consumer decision-making styles. Journal of Consumer Behavior, 3(4), 331-346. http://dx.doi.org/10.1002/cb.146

Mokhlis, S. Salleh, H. S. (2009). Consumer Decision-making Styles in Malaysia: An 
exploratory study of gender differences. European Journal of Social Sciences, 10(4), 574-584. Molosi, K. (2013). Education for all in Botswana. PhD Research Journal, University of Glasgow.

Moschis, G. P. (1976). Shopping orientations and consumer uses of information. Journal of Retailing, 52, 61-70.

National Development Plan 9. (2003/2008). Ministry of Finance and Development Planning. Government Printer, Republic of Botswana, Gaborone.

Nunnally, J. C., \& Bernstein, H. I. (1994). Psychometric Theory ( $3^{\text {rd }}$ ed.). New York. McGraw Hill.

Pandraud, R. L., \& Laurent, G. (2010). Why do older consumers buy older brands? The role of attachment and declining innovativeness. Journal of Marketing, 74(5), 104-121.

Policy Brief. (2008). Botswana: Trend in growth of modern retail and wholesale chains and relatedagric-business.Regoverning-markets. Retrieved January 5, 2013, from www.regoverningmarkets.org

Presidential Task Group. (1997). Vision 2016 Towards Prosperity For all: A long-term vision Radder, L. Li, Y., \& Pietersen, J. J. (2006). Decision-making styles of young Chinese, Motswana and Caucasian consumers in South Africa: An Exploratory Study. Journal of Family Ecology and Consumer Science, 34, 20-31.

Smadi, Z. M., \& Al-Jawazneh, B. E. (2011). The consumer decision-making styles of mobile phones among the University level students in Jordan. International Bulleting of Business Administration, 10, 104-121.

Sproles, G. B., \& Kendall, E. L. (1986). A methodology for profiling consumers' decision-making styles. The Journal of Consumer Affairs, 20(2), 267-279. http://dx.doi.org/10.1111/j.1745-6606.1986.tb00382.x

Sunday Standard. (2014). Standard Chartered confirms acquisition of 12 percent in Choppies. [Online]. Retrieved February 2, 2013, from www.sundaystandard.info

Turell, G. (2002). Socio-economic differences in food purchasing behavior and suggested implications for diet related health promotion. Journal of Human Nutrition and Dietetics, 15(5), 355-364.

UNICEF. (2004). [Online]. Retrieved January 5, 2013, from http://www.unicef.org/sowc04/file/sowc_04_eng

UNICEF. (2011). Botswana Annual Report. [Online]. Retrieved January 5, 2013, from http://www.unicef.org/botswana/BCO Annual Report_2011

Wal-Mart Corporate, Botswana: Social, Environmental \& Social Responsibility. [Online]. Retrieved January 5, 2013, from http://corporate.walmart.com/our-story/locations/botswana 
Walsh, G., Mitchell, V., \& Henning-Thurau, T. (2001). German consumer decision-making styles. The Journal of Consumer Affairs, 35(1). 73-95. http://dx.doi.org/10.1111/j.1745-6606.2001.tb00103.x

Wesley, S., LeHew, M., \& Woodside, A. G. (2006). Consumer decision-making styles and mall shopping behaviour: building theory using exploratory data analysis and the comparative method. Journal of Business Research, 59(5), 535-548. http://dx.doi.org/10.1016/j.jbusres,2006.01.005

Zeithaml, V. A. (1985). The new demographics and market fragmentation. Journal of Marketing, 49(3), 64-75.

\section{Copyright Disclaimer}

Copyright reserved by the author(s).

This article is an open-access article distributed under the terms and conditions of the Creative Commons Attribution license (http://creativecommons.org/licenses/by/3.0/). 